\title{
The Effect of Principal's Distributed Leadership Practice on Students' Academic Achievement: A Systematic Review of the Literature
}

\author{
Daniel Jambo ${ }^{1} \&$ Lei Hongde ${ }^{1}$ \\ ${ }^{1}$ School of Education, Huazhong University of Science and Technology Wuhan 430074, China \\ Correspondence: Lei Hongde, School of Education, Huazhong University of Science and Technology Wuhan \\ 430074, China
}

Received: November 12, 2019

Accepted: December 14, 2019 Online Published: December 18, 2019

doi:10.5430/ijhe.v9n1p189

URL: https://doi.org/10.5430/ijhe.v9n1p189

\begin{abstract}
Distributed leadership as a new scenario of educational leadership has become a popular topic in the contemporary world. Many notable researchers and members of the discourse community have contributed significantly to its development. However, little attention has paid to its effectiveness. Hence, the main purpose of this article is to analyze the existing evidence for the effect of principal's leadership practice on students' academic achievement from a distributed perspective. To do so, a systematic search of academic databases was conducted and 68 references spanning from the year 2001 to 2018 were selected and systematically reviewed. Due consideration was given to their concepts of distributed leadership practice, principal's role, and students' academic achievement. The findings of this article show that distributed leadership has positive and indirect effect on students' academic achievement and the role of principal is indispensable. Nevertheless, there is little emperical evidence, a lack of universal accepted patterns and best practices of distributed leadership which strains further investigation. On the basis of evidence currently available, it seems reasonable to recommend scholars, policy developers, and practitioners to recognize the role of principal on distributed leadership and its best practices.
\end{abstract}

Keywords: distributed leadership practice, principal's role, students' academic achievement, systematic review of literature

\section{Introduction}

In the present worldwide educational reform, school leadership has become a priority in educational policy. It plays an essential role in improving the school environment by influencing the motivation and capacity of teachers (Pont, Nusche and Moorman, 2008). Meanwhile, students' academic achievement is perceived and documented as the main objective of school reforms. The focus of many educational reform studies has shifted to analyze the relationship between leadership and students' achievement (Harris, 2008). Different scholars have also acknowledged that the role of leadership is the most significant factor for school effectiveness and students' academic achievement (Mulford 2003; Gentilucci and Muto 2007; Gamage 2009a). Their studies further revealed that the role of school leadership is to create and sustain an environment that maximizes teachers' ability to teach and students ability to learn, by focusing on people first, then on organizational structure and policies, and finally on the intended result of the change, that is academic achievement. Besides this, it has been found that effective leadership improves school climate and culture by motivating the staff and students for a higher level of academic achievement (Leithwood, Louis, Anderson and Wahlstorm, 2004). Moreover, many researchers agree that school principal is obligatory and accountable for students' achievement by building commitments and developing a shared vision to motivate the teachers and students (Mulford 2003; Gamage 2006a; Ross and Gray 2006; Spillane 2006).

This accountability as a new educational phenomenon has gained ground in the 21 st century. As a result, school principals are facing multiple challenges and complexity with regards to their preferences and practice of leadership style that have a positive effect on students' achievement. (Gamage, Adams and McCormack 2009). These challenges have a direct effect on school principals. Walker and Stott's (2000) study highlights principals and teachers surge experience feelings of failure, depression, and loss of temper. These stress related problems lead to higher staff member's turnover, and many principals have been losing their jobs. As a rebuttal to this point, a study by Harris (2008) noted that the old organizational structure of schooling does not fit the requirements of learning in this new millennium. To address this issue, new models of schooling are emerging based on collaboration, networking, and multi-agency leadership. Distributed leadership is one of these new perspectives of leadership 
approaches (Harris 2008; Tian 2016).

Hence, within the past two decades, distributed leadership (D.L) has emerged as a new educational leadership style. As Gronn (2000) notes as D.L has become a 'new child' within the stream of leadership approaches, this new model of educational leadership has received much more attention from academics, policy makers and practitioners (Spillane 2006; Harris 2008; Leithwood, Mascall and Strauss, 2009a). Many notable researchers have made significant contributions to its conceptualization and application. However, there is significant debate around the role of principal and its best practice (Bolden 2011; Tian, Risku and Collin, 2016). Moreover, there is a research gap in that little attention has been paid to the effectiveness of D.L. As such, the main purpose of this literature review is to analyze the effect of principal's D.L practice on students' academic achievement. The main objectives of this study are:

(1) to describe the effect of D.L practice on students' academic achievement,

(2) to identify the role of school principal on D.L, and

(3) to explore D.L practice problems and to recommend possible solutions.

\section{Methodology}

In order to address the above objectives, this literature review was conducted based on the guidelines suggested by Kitchenham and Charter (2007). This systematic procedure included three sequential stages: (a) Planning of the review, (b) Conducting the review and (c) Reporting the review.

\subsection{The First Step (Plan the Review)}

This stage of review began with need identification of the review. It refers to the specific objectives of the study, specific research questions and developing the review protocol to reduce the possible bias in the study. Thus, the following questions were developed by the researchers to guide the review.

Q1: What empirical evidence in the literature is there for effectiveness of D.L practices on students' academic achievement?

Q2: What endorsement in the literature is there for the role of the school principal on D.L?

Q3: What are the issues of principal D.L practice that should be studied in the future?

\subsection{The Second Step (Conducting the Review)}

This stage of review included search strategy, selection criteria, data extraction, data evaluation, and data analysis. This literature review was prepared by searching databases of different web sites through search engines of Google Scholar, Springer, Wiley, ERIC, pdfdrive, Academia and HUST library database. As a result, 707 references which were published from 2001 up to 2018 were retrieved. These include books, book chapters, dissertation, articles, conferences papers, and reports. These materials were manually organized and classified using mind maps and tables. By reading the title, abstract, and keywords of the materials, 486 references were excluded from this review due to their year of publication, language (non-English) and duplicates. Likewise, 61 of the references that had not been issued to the peer review process were omitted. Besides, 92 papers did not meet the inclusion criteria. The papers that did not meet the inclusion criteria or that meet any of the exclusion criteria were excluded from this study. 68 references were selected for this study. Their concept, self-report, key findings and commentary of interested writers were analyzed to examine the effect of principal leadership practice on students' academic achievement from a distributed perspective.

Table 1. Selection criteria checklist

\begin{tabular}{cc}
\hline Inclusion criteria & Exclusion criteria \\
\hline$-\quad$ Publication period between 2001-2018 & $-\quad$ Abstract only publications \\
$-\quad$ Issued to peer review & $-\quad$ Duplicates \\
$-\quad$ Publication language English & $-\quad$ Studies that did not deal with D.L, principal role, \\
$-\quad$ Present D.L concepts and framework & and students' academic achievement \\
$-\quad$ Integrate principal D.L practice with student's & $-\quad$ Papers with less than 5 pages \\
academic achievement & \\
Discuss principal role on D.L & \\
\hline
\end{tabular}


The selected references were categorized and summarized according to their type and publication date in the following table 2 .

Table 2. Classification of references based on types and publication date

\begin{tabular}{ccccccc}
\hline & & \multicolumn{5}{c}{ Year of Publication } \\
S/N & Type of Reference & $2001-2005$ & $2006-2010$ & $2011-2015$ & $2016-2018$ & Total \\
\hline 1 & Article & 7 & 10 & 15 & 6 & 38 \\
2 & Book & 7 & 2 & 1 & 1 & 11 \\
3 & Book chapter & 3 & 1 & - & 1 & 5 \\
4 & Dissertation & - & - & - & 2 & 2 \\
5 & Report \& conf. paper & 4 & 4 & 1 & 3 & 12 \\
& Total & 21 & 17 & 17 & 13 & 68 \\
\hline
\end{tabular}

According to Kitchenham and Charter's (2007) guidelines, the papers that were selected against the inclusion and exclusion criteria were assessed according to the research questions of the study. In addition, this study developed a data evaluation checklist and included the following items: Q1. Does the paper clearly state the purpose of the study? Q2. Does the paper address the main problem of the study? Q3. Does the paper present clear findings? Q4. Does the paper use research methodology with adquate sample size? Q5. Was the paper cited before? Moreover, a Likert scale with three values ( $1=$ Never, $2=$ partial contented, $3=$ full contented) was applied to describe every question for individual paper. The result of the quality assessment of this paper shows that 29 papers full contented the evaluation criteria and were used to extract and analyze the data.

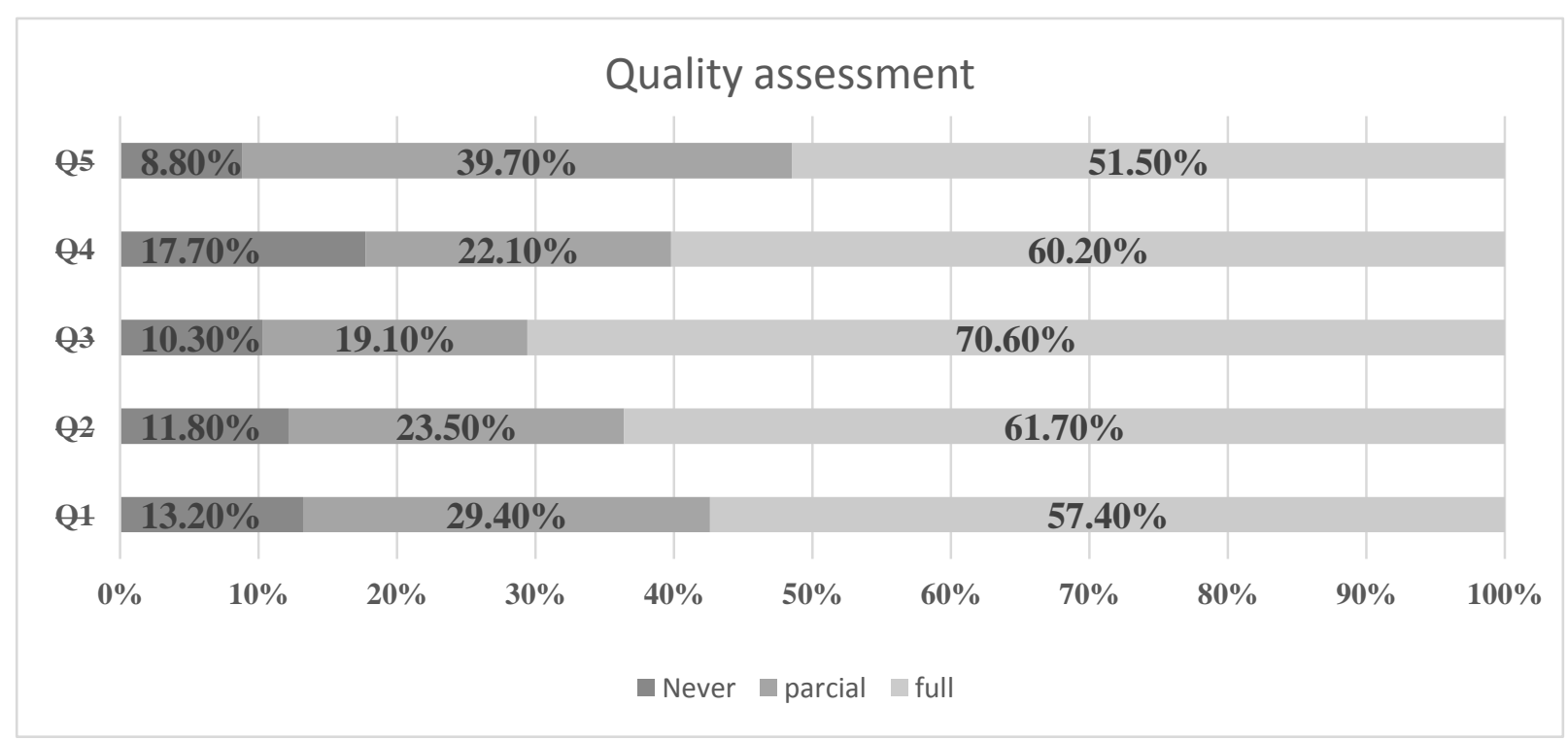

\subsection{Reporting the Review}

Figure 1. Result of quality assessment

This phase is the last stage of the review. It includes the results and discussions of the review. These are concepts and patterns of D.L, contempoary argumnets of D.L, principal role and students' academic achievemenet, and gaps of D.L studies. In order to discuss every finding and interpretation of the review, the researchers organized a regular weekly meeting and presented the report of the review in subsequent pages of this study.

\section{Concepts and Patterns of Distributed Leadership}

D.L as a term emerged and has been used by Australian psychologist Gibb in 1954. He used it to define that there is no single leader, and leadership is distributed. Moreover, he suggested that leadership behavior should not be considered as the domination of the solo leader in the organization, rather, it should be a shared function of the members. Later Groon (2000) acknowledged and stated Gibb as the first author of D.L and then developed the concept. Since then, a paradigm shift occurred from the 'heroic' model of leadership approach in which one person 
dominates and becomes responsible for leading an organization, to a model of D.L in which leadership is disseminated over the other members of the organization based on the features of their situation (Spillane 2006). However, D.L is perceived and conceptualized by different writers in distinctive ways. As a result, many arguments and critics have emerged. Works by Spillane, Halverson, and Diamond (2001) as well as a desk study by Bennett, Harvey, Wise and Woods (2003) noted that D.L as a new way of thinking about leadership has had a great impact on the school effectiveness. On the other hand, Macbeth (2005) concluded that D.L is a developing process that involves different forms of leadership practice. Spillane (2006) acknowledged that D.L is a framework for examining leadership, and asserted that the application of leadership could be transformed through the potentiality of the D.L tactic. In addition, some researchers have criticized D.L as if as a new convention of leadership style (Fitzgerald and Gunter 2006). Researchers also criticize that the definition of D.L is a catch-all view of leadership that interchangeably used with shared, collaborative, collective, participatory, democratic, and dispersed leadership (Bennet et al. 2003; Storey 2004; Bolden 2011).

However, a study by Harris (2013) clarified that the misunderstanding of D.L leads to many criticisms. This is due to the perception of different writers that interpreted it as if as every individual has equal leadership responsibility, authority, and accountability in the school. Moreover, her empirical study further highlighted that D.L as an ultimate reconceptualization of leadership practice has challenged conventional insight about the relationship between designated leaders and organizational achievement. Indeed, there is no internationally accepted definition and pattern of D.L. Tian et al. (2016) suggested that the most desirable frameworks of D.L have not yet been found, because that would have required a normative - prescriptive approach. However, there are some theoretical frameworks reviewed and summarized in this paper.

Spillane (2006) framework is encompassing the leaders - plus aspect and the practice centered aspect. Leading school by many leaders with leadership roles and responsibilities refers as leaders - plus aspect and practice centered aspect implies that leadership as interaction among leaders, followers and aspects of their situations. Spillane (2006) also added that the central factor for leadership is people and from the distributed perspective of leadership, it is critical to consider that how leadership practice take the figure in the interaction among leaders and followers.

A study by Liethwood, Mascall, Strauss, Sacks, Memon and Yashkina (2007) designed four frameworks of D.L in a very normative way that has had a great impact on the main objectives of the school. These are planful alignment, spontaneous alignment, spontaneous misalignment, and anarchic misalignment. Moreover, Leithwood (2007) and his colleagues asserted that both the misalignments have an adverse influence on organizational improvement and academic achievement. At the same time, their study strongly suggested that planful alignment is an effective pattern of D.L that have significant effect on students' achievement. This type of framework occurred in the school when there is participatory decision-making process that is based on discussion and reflection, clear job description, trust and respect among the followers and leaders. In addition, when there is cooperation rather than competition among those who work together.

Furthermore, a study by Tian (2016) identified four key themes of D.L using duality agency model and through the lenses of designated school leaders' and teachers' practices. These are (1), principals' essential role: (2), teachers' confined agency (3), socio-culturally determined structure and (4), pervasive power. Most of the previous frameworks emphasized the theoretical aspect of D.L by using descriptive analytical approach. Besides, they did not endorse any suitable methodology to emperically examine the effectiveness of D.L (Woods, Bennet, Harvey \&Wise, 2004; Tian et al. 2016).

\section{D.L as a Contemporary Scenario in School Leadership}

Many studies which have emerged in the past decade have claimed that there is a positive correlation between the practice of the distributed form of leadership and school improvement (Harris 2013; Harris \& Spillane 2008). D.L practice on professional learning communities makes a significant difference in students' achievement. Principals' D.L extends leadership responsibilities beyond principal which plays a crucial role for developing and sustaining effective professional learning communities in school (Louis 2007). A study by Copland (2003) noted that D.L in schools could be created and sustained when the set of leadership functions were shared across administration staffs, teachers, students, parents, and stakeholders of the school. Moreover, the work by Day et al. (2007) affirmed that D.L maximizes leadership capacity, increases followers understanding on individual role and responsibility through job description, and facilitates interaction and communication among them. Their study further noted and concluded that the role of the principal is a very crucial factor to develop and inspire a shared vision in school that cultivates citizenship and agency among the staff members. In addition, work by Murphy (2006) endorsed that D.L has the 
greatest impact on capacity building of the principal's self-efficacy and morale. Research evidence by Harris (2008) also highlights that D.L has great impact on organizational development. However, she asserted that operational hierarchy and cultural blockades could make it difficult for some teachers to practice leadership in the school. The planned alignment of leadership distribution is important and has a great positive effect than other leadership styles upon organizational change and improvement (Leithwood et al, 2009). However, this can be achieved through a principal who actively facilitates and supports others to act (Harris 2013; Klar, Huggins, Hammonds \& Buskey. 2016).

On the contrary, some writers argued that D.L in a school can bring conflict in prioritization of specific objectives and activities of the school. This refers to conflicts of leadership boundary issues: crossing hierarchical, cultural boundaries and competition in the staff members (Storey 2004; Timperely 2009). Along similar lines, Lumby (2013) argues that D.L ignores the political phenomenon of schooling where misuse and abuses of power related issues abound. A study by Woods (2004) also claimed that D.L was grounded in a narrow perception of the nature of human being, which primarily focused on developing intellectual as well as psychological dimensions of peoples. In addition, the work by Hulpia, Devos, Rosseel and Vlerick (2012) suggested that leaving teachers' teams to work alone without the principal's regular supervision could lead to low effectiveness.

Despite the above arguments, Grootemboer (2018) agreed with the original concept of D.L outlined by Groon (2002). The study further clarified that giving leadership opportunities to middle leaders can contribute significantly to filling the gaps of principals' leadership practice. Some researchers also argued that D.L could overstress teachers, however, involving them in decision making is a tenet of D.L that have positive impact to better achievement (Harris 2004 \& 2013; Timperley 2005; Dampson 2017). School leadership from a distributed perspective argues that leadership practice should be taken as the focus of interest and should also consider the staff members as leaders. This shows that leadership approach in terms of activities and interaction that are distributed across many individuals (Spillane 2006). Similarly, studies by Tian (2016) and Tian et al. (2016) assert the school principal was the most important human resource and also exercised the strongest agency in leading school administration, relationship building, and strategic development. Their study further confirmed the principal's support to be the key dynamic force behind teachers' participation in D.L. Furthermore, a study by Piot and Kelchtermans (2016) added that principals played a key role in balancing resource distribution and resolved conflicts across several schools. There is overwhelming evidence corroborating the notion that effectiveness of D.L approach is achieved through the principal (Murphy et al. 2009; Bush and Glover 2012; Harris 2013; Tian et al. 2016; Klar et al. 2016).

This paper has analyzed and presented the principals' role and students' achievement from a D.L perspective to address the following questions: Do school principals have a role on D.L? How principals practiced their role in the school? what is their effect on students' academic achievement?

\section{Principal D.L Practice and Students' Academic Achievement}

Currently available evidence of D.L shows that the role of the school principal has been changed from a single person leading and decision making attitude to sharing roles and responsibilities, sharing power and authority, inspiring vision and involving followers in decision making through influencing and interaction processes. These two processes become an as crucial slice of leadership practice in schools (Spillane 2006; Murphy, Smylie, Mayrowetz \& Louis. 2009; Day et al. 2009; Harris 2011). A study by Elmore (2000) added that school principal role from the distributed perspective is to ascertain capable persons who can lead in the school and to consolidate them towards the common goal based on their skills and role. Work by Day and Sammons (2016) affirmed that the inspiration of a clear vision is one of the key roles of effective principals. Yilmaz (2017) added that motivation is a powerful tool of principals D.L practice that enables followers to participate and practice leadership activities in a school. A study by Copland (2003) asserted that effective leaders embrace collaboration and delegation of power and duty through support and enable others to act leadership. D.L is effective when principal is willing to abandon power and give opportunity to staff members to lead (Pont et al, 2008; Harris, 2013; Dampson, 2017), but how is stimulating question which needs further investigation (Diamond \& Spillane, 2016; Tian, 2016). Moreover, involvement of followers in decision making has a positive impact on teachers' commitment and students' academic achievement (Cheng, 1994; Law, 2010; Jung, 2014). A principal who leads by being exemplary and who have active problem solving attitude shows leading ability of more effective institution (Joyce and Weil, 1996; Yokl, 2012; Kouzes and Posner, 1995 \& 2016).

Further empirical evidence leans towards supporting the relationship between D.L and student achievement. As a consequence of this, many researchers are coming to agreement that effective principals play a key role in improving school outcomes and students' achievement by creating conducive environment and enhancing followers' 
professional development (Pont, Nusche \& Moorman, 2004; Leithwood et al. 2004 \& 2009; Harris 2011; Miller, 2015; O' Donovan, 2015). A study by Leithwood et al. (2004) further confirms that behind every successful school there is an effective principal. In addition, some researchers have suggested that principal role should not be disregarded and miscalculated, because, D.L practice in school is strongly empowered as well as strongly limited by the principal (Spillane et al. 2007; Murphy et al. 2009; Harris 2013; Torrance \& Walter, 2015; Tian 2016).

Students' academic achievement is the intended goal of school that indicates students' performance that shows either better or poor outcomes. This can be the successful completion of course, program or educational level assured by educational authorities. Some researchers used it to measure institutional factors and some also used to measure the effectiveness of D.L through a standardized test, longitudinal test score, and graduation or grade level promotion (Heck and Hallinger 2010; Anderson, Moore \& Sun, 2009; Hulpia \& Devos, 2009; Malechwanzi 2018). The study by Tian (2016) asserted that the effectiveness of D.L was mainly measured by the attainment of an organizational goal, that is students' academic achievement. Many literature arguments appeared on the correlation between D.L practice and students' achievement in the past one and half decade. A study by Silins and Mulford (2002) confirmed that more D.L practice influence students' learning achievement. They draw the conclusion that students' academic achievements are improved by D.L sourced throughout the school community, and when teachers are motivated and encouraged by their leaders. Moreover, Copland (2003) argued that participatory and distributed patterns of leadership practices have positive trends in academic achievement. Similarly, Harris and Muiji's (2004) work revealed that there is a positive relationship between teachers' involvement in decision making, self-efficacy, and students' academic achievement. From comprehensive literature analysis on factors that influence students learning identified three broad conclusions by Pont et al. (2008). These are students background which is a most source of variation in students' achievement, educational policy which has a small portion of influence on student learning achievement and institutional (school) level variables which are the factors that have the strongest impact on students' achievement. Amongst these institutional factors, school leadership accounts for 25\% (Leithwood et al. 2004).

However, many writers' argument has preconditions on their study of D.L practice effect on students' achievement. A study by Pont et al. (2008) asserted that principals have the capacity, motivation and support quality that can make a significant contribution to learning improvement and students' achievement only if, they are granted the autonomy to make important decisions. Work by Harris \& Spillane (2008) also debated that the study of the correlation between D.L and academic achievement is only desirable and possible when the framework of leadership study connected with pedagogical literature. Similarly, Timperley (2009) argued that D.L is only desirable if the leadership practice supports teachers to be effective in instructing students. A study by Day, Sammons, Leithwood, Harris and Hopkins (2009) indicated that D.L is positively correlated with staff members' morale in particular and school situation in general. Their study also concluded that there is statistically significant relationship between more distribution of roles and responsibilities of leadership and school development as well as students' achievement. On the other hand, Anderson et al. (2009) claimed that the correlation between specific D.L patterns and student's achievement is unlikely to yield clear guidance practice. The relation between D.L and students' achievement provided different results in various contexts using the same patterns and definitions of D.L (Tian 2016). This implied that the effect of D.L on students' academic achievement depends on the context.

As mentioned above, D.L as a new approach of educational leadership, several related studies have been conducted for its conceptualization and application. Thus, this paper tried to answer the question of whether there is a research gaps and limitations on the developments and effectiveness of D.L studies.

\section{What is still Absent in D.L Studies?}

A meta-analysis (1996 - 2002) by Bennett and his collogues (2003) have intentionally selected and reviewed 80 publications on D.L and found that majority of the studies were based on qualitative methodology with a small scale. And the desk study by Bennett et al (2003) asserted that D.L is in its early stage and needs to examine the concerns relating its development, practice, and effectiveness on the school achievement using different methodology and large scale data. Moreover, some writers asserted that there are few studies that have used large scale data to investigate the effect of D.L approach on people, process or academic achievement (Leithwood et al. 2009; Timperley 2009; Harris 2011).

In addition, Meta-analysis (2002-2013) by Tian, Risku and Collin (2016) found that out of 21 empirical studies of D.L practice, six used a qualitative approach featuring interview, observations and case studies; seven adopted a quantitative method based on surveys; only five studies applied mixed methods, and the rest three studies were comparative in nature. And this Meta-analysis identified that most of the D.L studies exclusively represented research conducted in the Anglo-American world (Tian et al. 2016). Meanwhile, majority of the studies conducted in 
general education from kindergarten up to secondary level. Similarly, the present literature review found very few studies conducted in low-income countries, especially between the year 2013 to 2018 . During this period, there were only eight studies done in developing countries: five in Asia and three small scale studies in Africa that investigated ( in South Africa, Ghana, and Nigeria) the correlation between D.L and students' achievement. These indicate that there is a demand for supplementary inquiry of D.L effect on students' achievement in another context.

Moreover, work by Harris (2013) suggested that there is little empirical evidence pointing to the effectiveness of D.L practice on organizational achievement. Her study concluded that if further studies investigated the effectiveness of D.L practice, it is clear that formal leaders have a significant and integral role in facilitating D.L practice in the school. This implies that there is a demand for the examination that focused on the effect of principals' D.L practice on students' academic achievement. Furthermore, Diamond and Spillane (2016) suggested that still there have been few comparatively accurate interpretations of D.L practice and further investigation is needed. This implies that there is little attention paid for D.L effectiveness on students' academic achievement. A study by Tian (2016) also added that D.L is much more contextual and depends on practice and how it practiced in various socio-cultural context requires further investigation.

\section{Conclusion and Implication}

Most of the reviewed studies confirmed that the former organizational structure of schooling did not fit and satisfied the requirement of new millennium learning. As a result, a paradigm shift occurred from the heroic model of leadership in which single person dominates and become responsible for leading the school to a model of D.L style in which leadership spread over many followers of the school and characteristics of their situation. At the same time, the role of the principal has changed from solely leading and decision making attitude towards sharing roles, vision, power and involving followers in decision making through influencing and interaction processes. Based on the findings, the writers concluded that D.L is a complex phenomenon that has positive effect on students' academic achievement and the role of a principal is indispensable.

It is imperative that future study to be conducted on this particular topic. The researchers suggested that cross sectional and longitudinal studies should be undertaken on D.L to examine the issues relating to its best practice and effectiveness on academic achievement using normative perspective approach and different context. Moreover, this article recommends to policy makers and practitioners to give more attention to D.L practice through school principal and to consider that D.L is effective when school principal inspire shared vision, motivate followers, model the way, share power, enable others to act, focus on capacity building and involve others in decision making. Hopefully, this article will contribute to the ongoing research of D.L practice and its effectiveness.

\section{References}

Anderson, S., Moore, S. \& Sun, J. (2009). Positioning the principal in patterns of school leadership distribution. In K. Leithwood, B., Mascall, \& T. Strauss (Eds.), Distributed leadership according to the evidence. New York: Routledge,111-136. Http://toylorfrancis.com/books/e/9780203868539/9780203868539-15

Bennett, N., Harvey, J., Wise, C. \& Woods, P. (2003). Desk study review of distributed leadership, Nottingham, UK. Retrieved from http://www.ncsl.org.uk

Bierly, C., Doyle, B. \& Smith, A. (2016). Transforming Schools: How distributed leadership can create more high performing schools. Bain \& Company, Inc.Retrieved from Http:// www.bain.com/Images/BAINREPOT Transforming school Pdf.

Bolden, R. (2011). Distributed leadership in organizations. A review of theory \& research. International Journal of Management Reviews, 13(3), 251-269. http://dx.doi.org/10.1111/j.14682370.2011.00306

Bush, T. \& Glover, D. (2003). School leadership: Concepts \& Evidence, NCSL, Nottingham. Retrieved from http://www.ncsl.org.uk/literaturereviews

Bush, T. \& Glover, D. (2012). Distributed leadership in action: Leading high performing leadership teams in English Schools. School Leadership \& Management, 32(1), 21-36. http://doi.org/10.1080/13632434.2011.642354

Cheng, Y. (1994). Principals' leadership as a critical factor for school performance: Evidence from multilevel of primary schools. School Effectiveness \& School Improvement, 5, 299-317. http://doi.org/10.1080/0924345940050306

Copland, M. (2003). Leadership of inquiry: building \& sustaining capacity for school improvement. Educational Evaluation \& Policy Analysis, 25(4), 375-395. http://doi.org/10.3102/01623737025004375 
Dampson, D. (2017). Distributed Leadership an Instrument for School Improvement: The Study of Public Senior High School in Ghana. Journal of Science, Humanities \& Art, 5(1), 1-15. http://dx.doi.ord/10.17160/josha.5.1.374

Day, C., Sammons, P., Leithwood, K., Harris, A. \& Hopkins, D. (2007). Leadership \& Pupil Outcomes, Interim Report, London DCSF. http://dero.ioe.ac.uk

Day, C., Sammons, P., Leithwood, K., Harris, A. \& Hopkins, D. (2009). The Impact of Leadership On Pupil Outcomes, Final Report, London DCSF. http://dero.ioe.ac.uk/11329/DCSF-RR108.pdf.

Day, C. \& Sammons, P. (2016). Successful school leadership. Berkshire: Education Development Trust. http://doi.org/10.1177/089202061666593

Diamond, J. \& Spillane, J. (2016). School leadership \& management from a distributed perspective: A 2016 retrospective \& prospective. British Educational Leadership, Management \& Administration Society, 30(4), 147 -154. http://dx.doi.org/10.1177/0892020616665938

Elmore, R. (2000). Building a new structure for school leadership. Washington, DC: The Albert Shanker Institute. http://www.eric.ed.gov/?id=ED546618

Fitzgrald, T. \& Gunter, H. (2006). Teacher leadership? A new form of managerialism. New Zealand Journal of Education, 21(2), 44-57. http://hdl.handle.net/1959.9/451495

Fullan, M. (2001). Leading in culture of change. San Francisco, CA: Jossey-Bass. http://files.eric.org/fulltext/EDGroon, P. (2000). Distributed Properties: A new architecture for leadership. Educational Management \& Administration, 28(3), 317-338. http://doi.org/10.1177/0263211x000283006

Groon, P. (2002). Distributed leadership as a unit of analysis. Leadership Quarterly, 13(40, 423-451. http://doi.org/10.1016/SI048-9843(02)00120-0

Gamage, A. (2006). Professional Development for Leaders and Managers of Self-Governing Schools. Dordrecht, the Netherland: Springer. http://doi.org/10.1007/1-4020-4929-3

Gamage, A. (2009a). Leading Managing $21^{\text {st }}$ Century Schools for Improved Student Performance. Sydney, McGraw Hill.

Gamage, A. \& Mccormak, A. (2009). How Dos a School Leaders' Role Influence Student Achievements? Review of Research Findings and Best Practice. International Journal of Educational Leadership Preparation, 4(2), 1-16. http://cnx.org/content/m19751/1.2/

Gibb, J.R. (1954). Dynamics of participatory groups. St, Louis, MO: John Swift.

Gentilucci, J. \& Muto, K. (2007). Principals' Influence on Academic Achievement: The Student Perspective. The National Association of Secondary School Principals, Bulletin Sep. 2007. http://doi.org/10.1177/0192636507303738

Grootemboer, P. (2018). The Practice of School Middle Leadership: Leading Professional Learning. School of Education, Australia, Griffith University, Gold coast QLD. https://doi.org/10.1007/978-981-13-0768-3_2

Gunter, H., Hall, D. \& Bragg, J. (2013). Distributed leadership: A study in knowledge production. Educational Management, Administration \& Leadership, 41(5), 555-580. https://doi.org/10.1177/1741143213488586

Harris, A. (2008). Distributed Leadership: Developing Tomorrow's Leaders, Routledge, London. http://doi.org/10.4324/9780203607909

Harris, A. \& Mujis, D. (2004). Improving schools through teacher leadership. New York: Open University Press.

Harris, A. \& Spillane, J. (2008). Distributed leadership through the looking glass. British Educational Leadership, Management \& Administration Society, 122(1), 31-34. http://dx.doi.org/10.1177/0892020607085623

Harris, A. (2011). Distributed leadership: implication for the role of principal. Journal of Management Development, 31(1), 7-17. http://dx.doi.org/10.1108/02621711211190961

Harris, A. (2013). Distributed Leadership Matters: Potential Practicalities \& Possibilities, USA Corwin Press.

Harris, A. (2013). Distributed leadership: Friend or foe? Educational Management Administration \& Leadership 41(5), 545-554. http://dx.doi.org/10.1177/1741143213497635

Heck, R. \& Hallinger, P. (2010). Testing a longitudinal model of distributed leadership effect on school improvement. Leadership Quarterly, 21, 867-885. http://doi.org/10.1016/j.leaqua.2010.07.013 
Hulpia, H. \& Devos, G. (2009). Exploring the link between distributed leadership \& job satisfaction. Leadership Studies, 35, 153-171. http://doi.org/10.1080/03055690802648739

Hulpia, H., Devos, G., Rosseel, Y. \& Vlerick, P. (2012). Dimensions of distributed leadership \& the impact on teachers' organizational commitment. A study in secondary education. Journal of applied Social Psychology, 42(7), 1745-1784. http://dx.doi.org/10.1111/j.1559-1816.2012.00917.x

Jung, Y. (2014). Teacher Involvement in School Decision Making. Journal of Studies in Education, 4(3), 50-58. http://dx.doi.org/10.5296/jse.v4i3.6179

Kitchenham, B. \& S. Charters (2007). Guidelines for performing systematic literature reviews in software engineering version 2.3. Engineering 45(4ve): 1051. http://doi.org/10.1145/2372233.2372235

Klar, H., Huggins, K., Hammonds, H. \& Buskey, F. (2016). Fostering the capacity for distributed leadership: a postheroic approach to leading school improvement. International Journal of Leadership on Education, 19(2), 111137. http://doi.org/10.1080/13603124.2015.1005028

Kouzes, J. \& Ponser, B. (1995). The leadership challenges: How to get extraordinary things done in organizations ( $2^{\text {nd }}$ ed.). San Francisco: Jossey-Bass.

Kouzes, J. \& Ponser, B. (2016). The Leadership Challenge: How to Make Extraordinary Thing Happen in Organization $\left(5^{\text {th }}\right.$ ed.), Five practice of exemplary leadership, dissemination conference, Retrieved from http://www.leadershipchallenge.com

Leithwood, K. (1994). Leadership for school Restructuring. Educational Administration Quarterly, 30(4), 498-518. http://dx.doi.org/10.1177/001316x94030004006

Leithwood, K. \& Jantzi, D. (1999). The relative effects of Principal \& teacher sources of leadership on students' engagement with school. Educational Administration Quarterly, 35(5), 679-706. http://doi.org/10.1177/0013161x99355002

Leithwood, K., Louis, S., Anderson, S. \& Wahlstrom, K. (2004). Review of Research, How Leadership Influences Students Learning from Leadership Project, Wallace Foundation, New York, NY. http://eric.ed.gov/ED485932

Leithwood, K., Mascall, B., Strauss, R., Sacks, R., Menon, N. \& Yashkina, A. (2007). Distributing leadership to make schools smarter: Taking the ego out of the system. Leadership \& policy in schools, 6(1), 37-67. http://doi.org/10.1080/15700.760601091267

Leithwood, K., B. Mascall \& T. Strauss (2009). Distributed Leadership According to the Evidence, London, Routledge. http://doi.org/10.4324/9780203868539

Louis, K. (2007). Trust \& Improvement in Schools. Journal of Educational Change, 8(1), 1-24. http://doi.org/10.1007/s/0833-006-9015-5

Law, E., Galton, M. \& Wan, S. (2010). Distributed curriculum leadership in action. A Hong Kong case study. Educational management, Administration \& Leadership, 38(3), 286-303. http://doi.org/10.177/1741143209359714

Lumby, J. (2013). Distributed Leadership: The uses \& abuses of power. Educational Management, Administration \& Leadership, 41(5), 581-597. http://dx.doi.org/10.1177/1741143213489288

MacBeath, J. (2005). Leadership as distributed: a matter of practice. School Leadership \& Management, 25(4), 349366. http://dx.doi.org/10.1080/13634230500197165

Malechwanzi, J. (2018). The effect of College Resources \& Student Engagement on Learning Outcomes in Kenya's Higher Vocational Colleges: A study Based on Structural Equation Model, dissertation on educational economics \& management 10487, Huazhong University of Science \& Technology, China.

Miller, P. (2015). Leading Remotely. Exploring the experience of principals in rural \& remote school communities in Jamaica. International Journal of Whole Schooling, 11(1), 35-53. http://www.eric.ed.gov/?id=Ej1061016

Mulford, W. (2003). School Leaders: Challenging Role and Impact on Teacher \& School Effectiveness, a paper prepared for the OECD, Improving School Leadership Activity. http://semanticscholar.org

Murphy, J. (2006). Connecting Teaching Leadership and School Improvement. Thousand Oaks, CA: Corwin Press. http://researchgate.net/publication/260248082 
Murphy, J., Smylie, M., Mayrowetz, D. \& Louis, K. (2009). The role of the principal in fostering the development of distributed leadership. School Leadership \& Management, 29(2), 181-214. http://www.tandf.co.uk/jurnals

Piot, L. \& Kelchetrman, G. (2016). The micro politics of distributed leadership: Four case studies of school federations. Educational Management, Administration \& Leadership, 44(4), 632-649. http://doi.org/10.1177/1741143214559224

Pont, B., Nusche, D. \& Moorman, H. (2004). Improving School Leadership, Volume 1: Policy \& Practice, OECD, Paris.http://www.oecd.org/edu/school/44374889.pdf.

Pont, B., Nusche, D. \& Moorman, H. (2008). Improving School Leadership: Policy \& practice, Volume 1 OECD Paris. https://www.oecd.org/edu/school/44374889.pdf

Ross, J. \& Gray, P. (2006). School Leadership \& Student Achievement: The Mediating Effects of Teacher Beliefs. Canadian Journal of Education, 29(3), 798-822. http://www.eric.ed.gov

Spillane, J., Halverson, R. \& Diamond, J. (2001). Towards a Theory of Leadership Practice: A Distributed Perspective, Northwestern University, Institute for Policy Research Working Article. http://dx.doi.org/10.3102/0013189X030003023

Spillane, J., Halverson, R. \& Diamond, J. (2004). Towards a theory of leadership practice: a distributed perspective. Journal of curriculum studies, 36(1), 3-34. http://dx.doi.org/10.1080/0022027032000106726

Spillane, J. (2006). Distributed Leadership. San Francisco: Jossey-Bass.

Spillane, J., Camburn, E. \& Pareja, A. (2007). Taking a distributed perspective to the school principal work day. Leadership \& policy in schools, 6(1), 103-125. http://dx.doi.org/10.1080/15700760601091200

Storey, A. (2004). The problem of distributed leadership in schools. School Leadership \& Management, 24(3), 249 -265. http://doi.org/10.1080/1363243042000266918

Timerley, H. (2005). Distributed Leadership: Developing theory from practice. Journal of curriculum studies, 37(4), 395-420. http://dx.doi.org/10.1080/00220270500038545

Timperley, H. (2009). Distributed leadership to improve outcomes for students. In K. Leithwood, B. Mascall \& T. Strauss (Eds.), Distributed leadership according to the evidence. Abingdon: Routledge 197-222.

Tian, M., Risku, M. \& Collin, K. (2016). A meta-analysis of distributed leadership from 2002 to 2013: Theory development, empirical evidence \& future research focus. Educational Management, Administration \& Leadership, 44(1), 146-164.http://dx.doi.org/10.1177/1741143214558576

Tian, M. (2016). Distributed leadership in Finnish \& Shanghai schools. Jyväskylä studies in education, psychology \& social research(571).

Torrance, D. (2013). Distributed Leadership: Still in the gift of the head teacher. Scottish Educational Review, 45(2), 50-63. http://www.eric.ed.gov

Torrance, D. \& Walter, H. (2015). The shifting discourses of educational leadership. International trends \& Scotland's response. Educational Management, Administration \& Leadership, 43(5), 792-810.http://doi.org/10.1177/1741143214535748

Yilmaz, A. (2017). Distributed Leadership Behaviors Among Elementary School Teachers in Turkey. International Journal of Pedagogies \& Learning, 12(1), 41-61.

Yukl, G. (2002). Leadership in organizations. Upper Saddle River, NJ: Prentice-Hall. http://books.google.com

Yukl, G. (2012). Effective Leadership Behavior: What We Know \& What Questions Need More Attention. Academy of management Perspective, 66-85. http://doi.org/10.5465/amp.2012.0088

Retrieved from: http://www.researchgate.net/publication/276183421.

Walker, P. \& Stott, K. (2000). Performance Improvement in Schools. A case Overdoes? Educational Management, Administration \& Leadership, 28(1), 63-76. http://www.ema.sagepub.com

Woods, P., Bennet, N., Harvey, J. \& Wise, C. (2004). Variabilities \& dualities in distributed leadership. Educational Management, Administration \& Leadership, 32(4), 439-457. http://dx.doi.org/10.1117/17441143204046497 